\title{
ANALISIS KESULITAN BERPIKIR VISUAL DALAM MEMAHAMI KONSEP PADA MATERI HIMPUNAN
}

\author{
Meriana Loru Milla1, Firda Alfiana Patricia ${ }^{2}$, Raras Kartika Sari ${ }^{3}$ \\ 1,2,3 IKIP Budi Utomo Malang \\ raraskartikasari@gmail.com
}

\begin{abstract}
Abstrak
Matematika merupakan pelajaran yang selalu menjadi acuan kecerdasan serta ketuntasan proses pendidikan siswa kapanpun dan di manapun. Penelitian bertujuan untuk melakukan analisis kesulitan pada siswa kelas VII SMP Negeri 4 Wewewa Timur dalam memahami konsep materi matematika yaitu himpunan. Penelitian ini termasuk dalam jenis penelitian kualitatif deskriptif. Subjek penelitian adalah enam orang siswa. Instrumen dalam proses pengumpulan data adalah pedoman wawancara dan lembar tes soal. Penelitian ini menggunakan teknik pengumpulan data meliputi metode tes, metode wawancara, dan dokumentasi. Hasil dari proses penelitian didapatkan bahwa kesulitan siswa kelas VII SMP Negeri 4 Wewewa Timur dalam menyelesaikan soal pada materi himpunan sebagai berikut: 1) kesulitan menggunakan konsep; 2) kesulitan melakukan operasi dasar matematika dan operasi penjumlahan dan pengurangan; 3) kesulitan memahami soal cerita dan menentukan hal yang dibutuhkan dalam menyelesaikan persoalan tersebut. Kesulitan siswa disebabkan oleh beberapa faktor yaitu 1) faktor internal, penyebab kesulitan yang berasal dari dalam diri siswa itu sendiri; dan 2) faktor eksteren, Kesulitan siswa yang disebabkan dan berasal dari luar diri siswa tersebut. Berdasarkan hasil tes wawancara faktor-faktor yang mempengaruhi siswa dan menjadi penyebab kesulitan belajar siswa yaitu: 1)rendahnya kapasitas atau intelegensi siswa; 2) tidak percaya diri, 3)ketidakmampuan belajar matematika; 4) ketidakmampuan belajar membaca; dan 5) pengaruh dari lingkungan sekitar siswa.
\end{abstract}

Kata kunci: kesulitan, visual, matematika.

\begin{abstract}
Mathematics is a lesson that is always a reference to intelligence and completeness of the process of student education anytime and anywhere. The research aims to analyze the difficulties in the seventh grade students of SMP 4 Wewewa Timur in understanding the concept of mathematical material, namely set. This research is included in the type of descriptive qualitative research. The research subjects were six students. Instruments in the process of collecting data are interview guidelines and question test sheets. This study uses data collection techniques including test methods, interview methods, and documentation. The results of the research process found that the difficulty of class VII students of SMP Negeri 4 Timur in solving questions in the set material as follows: 1) difficulty using the concept; 2) difficulties in carrying out basic mathematical operations and addition and subtraction operations; 3) difficulty understanding the
\end{abstract}


problem of the story and determining the things needed to solve the problem. Student difficulties are caused by several factors, namely 1) internal factors, causes of difficulties that originate from within the student itself; and 2) external factors, student difficulties caused and originating from outside the student. Based on the results of the interview test the factors that influence students and become the cause of student learning difficulties are: 1) low capacity or intelligence of students; 2) not confident, 3)mathematics learning disabilities; 4) learning disability and 5) the influence of the environment around students.

Keywords: difficulties, visual, mathematics

\section{PENDAHULUAN}

Pendidikan identik dengan usaha sadar untuk menyiapkan siswa melalui pengajaran, bimbingan untuk mempersiapkan peranan siswa dimasa yang akan datang. Pendidikan direncanakan oleh pendidik dalam usaha untuk mewujudkan proses pembelajaran dan suasana pembelajaran yang aktif. Pendidikan ditujukan untuk mengembangkan potensi agar memiliki spiritual, pengendalian diri, kepribadian dan kecerdasan peserta didik.

Matematika merupakan mata pelajaran yang sudah ada sejak pendidikan dasar hingga pendidikan tinggi. Banyak siswa dalam pembelajaran matematika mengalami kesulitan pada proses pemahamannya. Matematika dianggap sebagai pelajaran yang menakutkan. Karasteristik matematika merupakan suatu ilmu dengan pola berpikir dan pembuktian yang logis (Subandar, 2008).
Perubahan tingkah laku secara keseluruhan di dapatkan dari hasil pengalaman dalam interaksi dengan lingkungan pada proses belajar (Slameto, 2010). Proses belajar matematika digunakan sebagai saran berpikir logis, dan sarana menyelesaikan masalah dalam kehidupan, serta sebagai sarana mengenal pola hubungan, dan sarana pengembangan kreatifitas (Cornelius; 2000).

Beberapa materi matematika dapat dengan mudah dipahami tetapi juga ada materi yang tidak mudah siswa pahami. Penyebab terjadinya kesulitan siswa karena adanya faktor yang menghambat pemahaman siswa baik faktor internal ataupun faktor eksternal. Peran guru sangat dibutuhkan untuk mengetahui penyebab kesulitan, apakah yang menyebabkan siswa mengalami kesulitan dalam pemahaman pelajaran matematika khususnya himpunan.

Rendahnya hasil belajar siswa dalam proses pembelajaran matematika disebabkan oleh 
beberapa faktor. Media pembelajaran yang kurang lengkap, fasilitas yang tidak layak pakai, dan kurikulum yang susah dijabarkan oleh pendidik dan sulitnya siswa dalam menguasai penjabaran kurikulum dari pendidik menjadi salah satu faktor yang menyebabkan kesulitan belajar matematika. Berbagai materi dalam matematika menjadi materi yang dianggap sulit oleh siswa yang mengalami kesulitan belajar maupun yang tidak berkesulitan belajar (Abdurahman, 1999).

Kesulitan belajar siswa terlihat dalam bentuk kesulitan yang nyata, terutama dalam kemampuan mendengar, berbicara, membaca, menalar, menulis dalam kemampuan matematika (Abdurrahman, 2010). Kesulitan belajar merupakan kelainan yang membuat siswa merasa kesulitan untuk melakukan kegiatan belajar secara efisien dan efektif.

\section{METODE PENELITIAN}

Penelitian dilaksanakan dengan menggunakan penelitian deskriptif kualitatif. Penelitian kualitatif bertujuan untuk mendeskripsikan kesulitan matematika pada subjek penelitian kemudian dideskripsikan.

Penelitian ini berfokus pada perubahan persepsi, perilaku, tindakan , dan motivasi, yang dijabarkan secara holistic. Hasil penelitian di deskripsikan dalam bahasa dan kata-kata pada suatu konteks khusus dengan memanfaatkan beberapa metode ilmiah Moleong, 2010).

Penelitian dilaksanakan di SMP Negeri 4 Wewewa Timur, Sumba Barat, Provinsi Nusa Tenggara Timur. Subjek penelitian dipilih enam siswa kelas VII SMP Negeri 4 Wewewa Timur Tahun Ajaran 2017/2018. Enam subjek mewakili masing-masing dua siswa dengan berbagai tingkat kemampuan yaitu kemampuan tinggi, kemampuan sedang dan kemampuan rendah.

Data penelitian dikumpulkan dengan menggunakan tes, wawancara dan observasi. Analisis data didapatkan dari hasil analisis observasi, hasil tes kemudian dikolabrasikan dengan analisis hasil transkrip wawancara dengan subjek penelitian.

\section{HASIL DAN PEMBAHASAN}

Hasil dari proses pengumpulan data pada penelitian analisis kesulitan berpikir visual dalam memahami konsep pada materi himpunan siswa kelas VII SMP Negeri 4 Wewewa Timur masih sangat kurang karena siswa siswi masih kesulitan dalam mengerjakan soal yang diberikan oleh peneliti,maka peneliti akan mengadakan belajar kelompok, atau didkusi kelompok dalam kelas agar siswa benar-benar 
mengerti dan memahami dengan baik.

Berdasarkan hasil penelitian kesulitan ang dialamioleh siswa dalam memahami materi himpunan antara lain: 1)kesulitan memahami konsep; 2)kesulitan membuat diagram Venn; 3) kesulitan dalam pengoperasian; 4) kesulitan seara teknis.

Siswa mengalami kesulitan pada bagian operasi hitung pengurangan. Hal ini disebabkan karena siswa tidak memahami konsep matematika pada himpunan kedalam bentuk diagram venn, sehingga siswa tidak maksimal dalam menyelesaikan.

Siswa juga tidak memahami perintah hal ini dapat dilihat bahwa apa yang ditanyakan tidak terjawab. permasalahan ini mengarah kepada siswa kurang teliti dalam hitungan sehingga hasil yang diperoleh tidak sesuai dengan jawaban.

Siswa mengalami kesulitan dalam pengoperasian hitung sehingga siswa mengerjakan seadanya dan asal-asalan dan siswa kurang teliti dalam pengerjaan soal matematika. Siswa hanya memahami konsep matematika setengah saja sehingga tidak menyelesaikan soal dengan sempurna.

Hasil observasi pembelajaran tentang himpunan di kelas VII A diketahui bahwa pembelajaran selama ini yang dilakukan oleh pengajar sangatlah kurang memotivasi para siswa dan perhatian yang kurang terhadap siswa yang kurang bisa memahami materi pelajaran sepenuhnya, metode yang selama ini digunakan adalah metode konvensional atau metode ceramah dimana guru hanya memberikan penerangan atau ceramah didepan kelas dan siswa hanya duduk dan mendengar.

\section{KESIMPULAN DAN SARAN}

Merujuk pada Hasil penelitian dapat disimpulkan bahwa kesulitan berpikir visual adalah proses ide, intelektual, dan imajinasi visual dalam pencintraan mental melalui gambar.

Kesulitan belajar yang dihadapi oleh siswa dalam pembelajaran matematika khusunya pada pokok bahasan himpunan yaitu pada pemahaman konsep.

Kesulitan belajar terjadi karena siswa kurang menguasi materi, rendahnya keterampilan siswa dalam memahami permasalahan pokok bahasan himpunan sehingga tidak dapat melakukan pemecahan masalah.

Penelitian ini diharapkan dapat dijadikan sebagai masukan pemikiran dalam peningkatan mutu pendidikan, khususnya dalam pengajaran materi matematika di SMP Negeri 4 Wewewa Timur.

Penelitian selanjutnya disarankan untuk melaksanakan 
Milla, M. L., Patricia, F. A., Sari, R. K.

Analisis Kesulitan Berpikir Visual Dalam Memahami Konsep Pada Materi Himpunan

penelitian lanjutan dengan cakupan materi serta ruang lingkup penelitian yang lebih luas.

\section{DAFTAR PUSTAKA}

Abdurahman. 2010. Pendidikan Bagi Anak Berksesulitan Belajar. Jakarta: Rineka Cipta.

Cornelius, J. 2000. Belajar Matematika Suatu Telaah Stategi Belajar Efektif. Jurnal Insitut Teknologi Sepuluh November Surabaya.

Mulyono. 2010. Pendidikan Bagi Anak Berksesulitan Belajar Jakarta: Rineka Cipta.

Slameto. 2010. Belajar dan FaktorFaktor yang Mempengaruhi. Jakarta: Rineka Cipta.

Subardar, J. (2008). Pembelajaran Matematika Sekolah dan Ketuntusan Belajar Matematika. Bandung: Universitas Pendidikan Indonesia. 